Original Research

\title{
Polycyclic Aromatic Hydrocarbons Contamination of Soil in an Industrial Zone and Evaluation of Pollution Sources
}

\author{
Predrag Ilić1*, Tatjana Nišić ${ }^{2}$ Zia Ur Rahman Farooqi ${ }^{3}$ \\ 'PSRI Institute for Protection and Ecology of the Republic of Srpska, Vidovdanska 43, Banja Luka, \\ Republic of Srpska, Bosnia and Herzegovina \\ ${ }^{2}$ City of Banja Luka, Trg Srpskih Vladara 1, Banja Luka, Republic of Srpska, Bosnia and Herzegovina \\ ${ }^{3}$ Institute of Soil and Environmental Sciences, University of Agriculture, Faisalabad-38040, Pakistan
}

Received: 9 January 2020

Accepted: 16 March 2020

\begin{abstract}
The levels of polycyclic aromatic hydrocarbons (PAHs) were determined in the industrial zone, near the center of Banja Luka and river Vrbas, Republic of Srpska, Bosnia and Herzegovina. In the presented research, the total concentration of the PAHs in research area ranged from 0.356 to $11.49 \mathrm{mg} / \mathrm{kg}$, with mean values of $1.99 \mathrm{mg} / \mathrm{kg}$ indicated that soil was heavily contaminated (max limit $1 \mathrm{mg} / \mathrm{kg}$ ) and polluted with pollutant of class III ranging from 1 to $5 \mathrm{mg} / \mathrm{kg}$. The possible sources of PAHs in the soils were estimated by using diagnostic ratios (LMW/HMW (low/high molecular weights), Fluo/(Fluo+Pyr) (fluoranthene/(fluoranthene+pyrene)), BaA/(BaA+Chr) (benzo[a]anthracene/(benzo[a] anthracene+chrysene)) and IcdP/(IcdP+BghiP) (indeno[1,2,3-cd]pyrene/(indeno[1,2,3-cd]pyrene + benzo[g,h,i]perylene))) and factor analysis (principal component analysis). The ratios showed that the PAHs in soil have both pyrogenic and petrogenic sources. Pyrogenic source is predominant. Petrogenic sources also have a significant contribution in the study area. Principal component analysis has shown that both industrial and human activities are the cause of pollution. The first factor is in relation to burning (pyrogenic origin). This factor explained $76.72 \%$ of total variance. The second factor is petrogenic, with $7.81 \%$ of total variance. PAHs in research area is a result of in general anthropogenic factors.
\end{abstract}

Keywords: soils, contamination, PAHs, factor analysis

\section{Introduction}

During the preliminary investigations at the subjected site, Polycyclic Aromatic Hydrocarbons

*e-mail: predrag.ilic@institutzei.net

(PAHs) concentrations were not tested [1]. Due to a high contamination with heavy metals and organic pollutants, research has now continued and determination of PAHs concentrations.

PAHs are a group of ubiquitous persistent organic pollutants [2, 3] and one of the most common pollutants in the industrial and urban regions [4] and they tend to accumulate in soil for longer time [5]. PAHs are toxic, 
carcinogenic and mutagenic to all living organisms [3, 6-10]. They are widespread in environment media such as air, water and soils [3]. Soil is the most important sink of PAHs in the environment [11]. Soils also act as one of the re-emission sources for PAHs contamination in air and soil sediments [12, 13]. Most of the PAHs having anthropogenic origin are adsorbed to the top layer of the soil [14].

PAHs are primarily formed through the incomplete combustion of carbon containing fuels such as wood, diesel, coal and fat. Most common source of PAHs are anthropogenic activities, i.e. industrial emissions, incomplete combustion of fossil fuel and organic materials, solid waste incineration and vehicular emissions [3, 13, 8].

Sixteen (16) PAHs types are categorized on the basis of priority for their control by US Environmental Protection Agency (EPA) [13]. These are classified in two main groups of compounds related to the number of aromatic rings: low molecular weights PAHs (LMWPAHs) with 2-3 aromatic rings (naphthalene (Nap), acenaphthylene (Acy), acenaphthene (Ace), fluorine (Flo), phenanthrene (Phe) and anthracene (Ant)) and high molecular weight PAHs (HMWPAHs) with 4-6 aromatic rings such as fluoranthene (Fluo,) pyrene (Pyr,) benzo[a]anthracene (BaA), chrysene (Chr), benzo[b]fluoranthene $(\mathrm{BbF})$, benzo[k]fluoranthene $(\mathrm{BkF})$, benzo[a]-pyrene $(\mathrm{BaP})$, indeno[1,2,3-cd]pyrene (IcdP), dibenzo[a,h]anthracene (DahA) and benzo[g,h,i] perylene (BghiP). PAHs from petrogenic source are formed predominantly with those of low molecular weights (LMWPAHs), whilst the PAHs from a pyrogenic source generally have high molecular weights (HMWPAHs) [15, 3].

The presented study is important because it will constitute the first local survey carried-out in industrial areas of Banja Luka. This research is focused on the presentation and discussion of the data related to contamination of soils by PAHs. The primary aim of this study was to measure the concentrations of PAHs in soil, estimate their probable sources using diagnostic ratios and principal component analysis in industrial complex Incel, Banja Luka, Republic of Srpska, Bosnia and Herzegovina.

Determining the PAHs concentration in PAHcontaminated soil is an important step for environmental remediation in future studies [8]. Location is hotspot of PCB and heavy metals [1] and probable hotspot of PAHs in Banja Luka, Republic of Srpska, Bosnia and Herzegovina.

\section{Material and Methods}

\section{Location}

Banja Luka is the second biggest city in Bosnia and Herzegovina with the population of 185,000 . The city is situated in a basin $164 \mathrm{~m}$ above sea level. The average annual temperature reaches $10.7^{\circ} \mathrm{C}$. The subject of the research was to measure the PAHs concentration in the soil on the locality Incel (former Cellulose Factory, now industrial complex) in the city of Banja Luka, $(3 \mathrm{~km}$ distance from the centre). The survey included 35 soil samples $(0-20 \mathrm{~cm}$ top layer). The samples were taken from an area of about 10 hectares.

\section{Sampling and Analysis}

Samplings were performed in 35 location in industrial complex, during May-June 2019. Locations sampling of the soil was carried out with sampling equipment, Eijkelkamp Agrisearch Equipment, Netherlands. Chemical analyses were conducted for all 16 types of PAHs by Gas chromatography. The detector used for PAH analysis is a mass detector coupled with the gas chromatograph (GC-MS).

Quality assurance and control (QA/QC) was attained following strict quality assurance and control measures. The identification of the source of uncertainty was made on the basis of the uncertainty arising from the GC-MS (sample capture), the preparation of standard solutions for the calibration of the instrument, the measurement of the sample, the accuracy of sample measurement in a normal vessel, the measurement of the volume of the concentrated extract and the uncertainty arising from the variation of temperature.

In order to obtain experimental results for soil, the method of spiking the sample matrix - blind trials with the known amount of analytes tested and analysis of the control samples thus obtained was used. The verification procedure covers the following parameters: instrument calibration, repeatability, return, limit of detection (LOD) and limit of quantification (LOQ). The validation of the analytical method was also carried out through a recovery study. The spiked samples were analyzed in the same way as actual samples. Instrument calibration was done using certified analytical standards. A series of 5 standard solutions were prepared. Linearity was tested in the concentration range from $0,03-0.66 \mathrm{mg} / \mathrm{kg}$ (in the sample), i.e. from $100-2000 \mu \mathrm{g} / 1$ for soil.

The obtained PAHs concentrations were further processed based on the principles described in Standard Methods with disintegration techniques and analysed in accordance with national legislations [16] and accredited standard method EPA 8270D/3550C:2007. Accredited quantification limit for $\mathrm{PAH}$ in soil is $0,02 \mathrm{mg} / \mathrm{kg}$.

\section{Statistical Analysis}

Descriptive statistical operations like mean, median, standard deviation (SD), variance, minimum (min), maximum (max), Skewness and Kurtosis test applied for analysis of the measured data. Factor analysis (principal component analysis) for PAHs components was applied for getting the qualitative information of the source of the 16 components of PAHs. The Excel 2016 and JASP v0.8.5.1 software tools were used for statistical data processing. 


\section{Results and Discussion}

Table 1 shows the descriptive statistics of the 16 PAHs compounds in soils found on the sample 35 locations of the studied area. PAHs are considered among the most dangerous pollutants [17]. In this study, the total concentration of the PAHs ranged from 0.36 to $11.49 \mathrm{mg} / \mathrm{kg}$, with mean values of $1.99 \mathrm{mg} / \mathrm{kg}$. Mean values indicated that soil were heavily contaminated against the permissible limits of $1 \mathrm{mg} / \mathrm{kg}$ [17] and polluted with pollutant of class III ranging from 1 to $5 \mathrm{mg} / \mathrm{kg}$ [19] Values are in line with the values which were found during research in Lisbon Urban Soils [18] and urban soils of southern Poland [10].

As can be seen that Pyr is the component with the highest mean concentration $(0.28 \mathrm{mg} / \mathrm{kg})$, followed by Nap and Acy, with mean concentration $0.19 \mathrm{mg} / \mathrm{kg}$. Phe, as marker of wood and coal combustion [20], is component with the lowest mean concentration $(0.06 \mathrm{mg} / \mathrm{kg})$.

These values are higher than the concentrations which are found in urban and rural areas of Southern Italian soils [3].

Skewness and Kurtosis were used to test the normality of a given data set. Skewness is less than -1 or greater than 1 and the distribution is highly skewed. Skewness test for all analyzing parameters have shown that data distribution is not normal. Coefficient of variation (CV), as an index showing the extent of variability in relation to the mean of the samples, which can be used for identifying the anthropogenic contribution degree for pollution in the environmental studies [21]. In this research, CV is very high. If mean of $\mathrm{CV}>0.90$, its value indicates high anthropogenic contributions [22], which confirms that it is high anthropogenic impact. Analyzing pollutant (PAHs) have $\mathrm{CV}>0.90$. Values for PAHs components also have $\mathrm{CV}>0.90$. These values indicates high anthropogenic contribution and concentrations of PAHs in the soil samples varied significantly from location to location. In general, $\mathrm{CV}$ exceeded $58 \%$ for all compounds, which confirmed the heterogeneity of soil samples. This suggests that the PAHs components might have been affected by multiple factors [23].

The highest values of SD and $\mathrm{CV}$ were characteristic of $\mathrm{BbF}$ and $\mathrm{BkF}(0.20 / 0.19$ and 182.14/197.94).

Due to the variations in PAHs concentrations in different sampling sites, it is necessary to identify and determine the sources of PAHs pollution in samples. The sources of PAHs can be summarized into three groups: petrogenic, pyrogenic and phytogenic [8]. One of the most common approaches for determining the sources of PAH is isomeric ratios [17]. Diagnostic ratios provide source identification information and average ratios can represent the major sources [24]. Four specific diagnostic molecular ratios of PAHs were used for the identification of PAHs pollution sources: LMW/ HMW, Fluo/(Fluo+Pyr), IcdP/(IcdP+BghiP) and $\mathrm{BaA} /$ (BaA+Chr) [3, 8] (Fig 1).

Table 1. Descriptive statistical of the PAHs.

\begin{tabular}{|c|c|c|c|c|c|c|c|c|c|c|c|}
\hline PAHs $(\mathrm{mg} / \mathrm{kg})$ & Mean & Median & Std. Dev. & Var. & Skew. & Kurt. & CV & Range & Min & Max & Sum \\
\hline BbF & 0.11 & 0.02 & 0.20 & 0.04 & 2.58 & 6.52 & 182.14 & 0.85 & 0.003 & 0.851 & 3.80 \\
\hline BkF & 0.09 & 0.02 & 0.19 & 0.04 & 2.89 & 8.83 & 197.94 & 0.87 & 0.004 & 0.876 & 3.32 \\
\hline BaP & 0.12 & 0.03 & 0.19 & 0.04 & 2.41 & 5.77 & 162.45 & 0.82 & 0.009 & 0.831 & 4.07 \\
\hline BghiP & 0.1 & 0.02 & 0.18 & 0.03 & 2.40 & 4.82 & 181.84 & 0.70 & 0.003 & 0.699 & 3.52 \\
\hline IcdP & 0.11 & 0.03 & 0.19 & 0.03 & 2.88 & 9.43 & 171.54 & 0.89 & 0.006 & 0.897 & 3.79 \\
\hline Ant & 0.13 & 0.06 & 0.20 & 0.04 & 3.12 & 10.00 & 157.36 & 0.90 & 0.009 & 0.909 & 4.52 \\
\hline Chr & 0.09 & 0.02 & 0.15 & 0.02 & 2.58 & 6.67 & 174.64 & 0.66 & 0.007 & 0.67 & 3.05 \\
\hline DahA & 0.1 & 0.03 & 0.16 & 0.03 & 2.31 & 4.75 & 157.97 & 0.64 & 0.008 & 0.643 & 3.63 \\
\hline Acy & 0.19 & 0.12 & 0.16 & 0.02 & 1.07 & 0.28 & 82.04 & 0.61 & 0.012 & 0.625 & 6.68 \\
\hline Pyr & 0.28 & 0.28 & 0.17 & 0.03 & 0.45 & 0.14 & 58.96 & 0.68 & 0.031 & 0.707 & 9.92 \\
\hline BaA & 0.12 & 0.05 & 0.17 & 0.03 & 2.65 & 7.14 & 139.36 & 0.74 & 0.014 & 0.75 & 4.20 \\
\hline Phe & 0.06 & 0.01 & 0.15 & 0.02 & 4.38 & 21.76 & 228.01 & 0.82 & 0.009 & 0.825 & 2.26 \\
\hline Flo & 0.08 & 0.03 & 0.13 & 0.02 & 2.96 & 8.81 & 153.25 & 0.57 & 0.012 & 0.585 & 2.97 \\
\hline Nap & 0.19 & 0.14 & 0.18 & 0.03 & 1.78 & 4.11 & 93.38 & 0.81 & 0.026 & 0.833 & 6.62 \\
\hline Ace & 0.09 & 0.07 & 0.10 & 0.01 & 2.57 & 7.83 & 111.55 & 0.51 & 0 & 0.513 & 3.23 \\
\hline Fluo & 0.12 & 0.05 & 0.19 & 0.04 & 3.12 & 10.01 & 160.20 & 0.85 & 0.01 & 0.859 & 4.13 \\
\hline$\sum 16$ PAHs & 1.99 & 1.24 & 2.36 & 5.55 & 2.97 & 9.47 & 118.28 & 11.13 & 0.356 & 11.49 & 69.70 \\
\hline
\end{tabular}


The LMW/HMW ratios (Fig. 1) were interpreted in terms of source apportionment. Soils from industrial areas from Banja Luka (former industrial complex Incel) displayed a higher mean value compared to those from urban areas, with the mean value of 0.93 (from 0.2 to 2.5). These values indicate that the most likely sources of PAHs in the research area may be related to emissions from pyrogenic combustion [25]. This was referred to petroleum sources as the primary
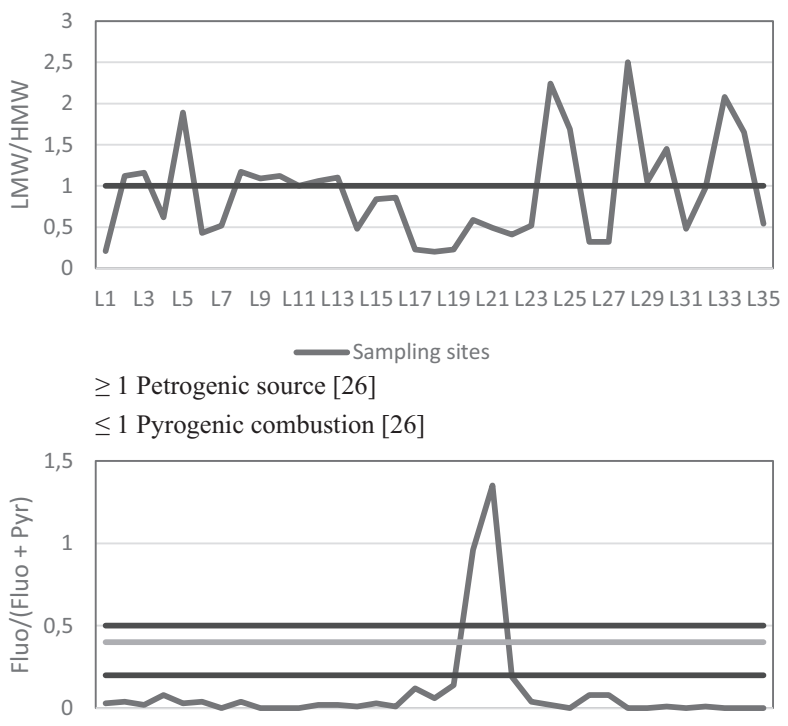

L1 L3 L5 L7 L9 L11 L13 L15 L17 L19 L21 L23 L25 L27 L29 L31 L33 L35 Sampling sites

0.5 Biomass and coal combustion [27] 0.4-0.5 Fossil fuel combustion [27]

$<0.20$ Petroleum/ petrogenic source [27]

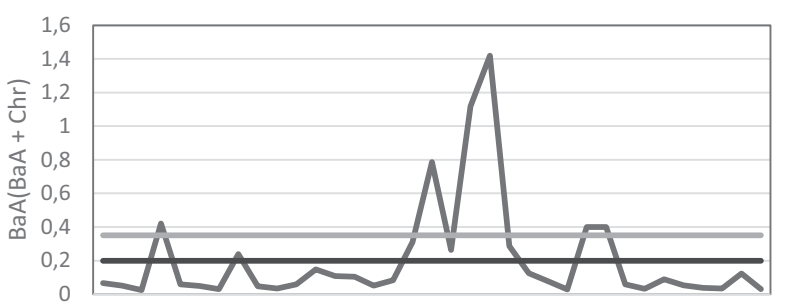

L1 L3 L5 L7 L9 L11 L13 L15 L17 L19 L21 L23 L25 L27 L29 L31 L33 L35

$>0.35$ Traffic emission [27]

0.2-0.35 Coal combustion [27]

$<0.20$ Petrogenic source [28]

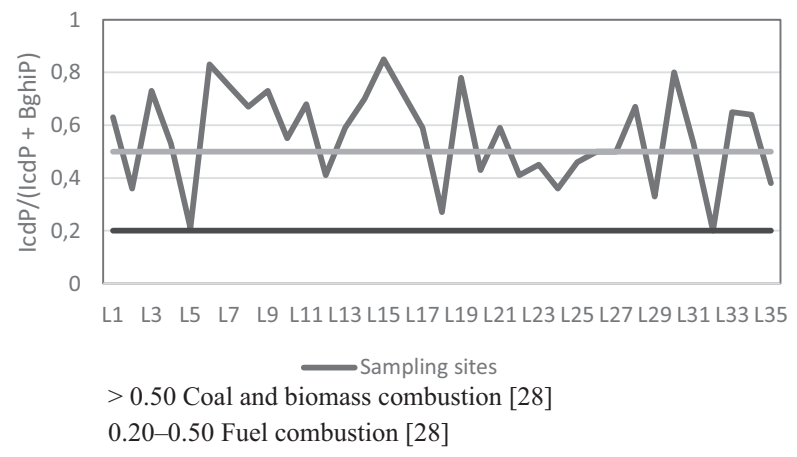

Fig. 1. Diagnostic molecular ratios of PAHs: LMW/HMW, Fluo/ (Fluo+Pyr), BaA/(BaA+Chr) and IcdP/(IcdP+BghiP). source for PAHs in this area. Previously, the site was heat and power plant. Now, there is Banja Luka Heating Plant near the complex Incel. This plant can give rise to 'pyrogenic combustion' emissions of PAHs, partially and petrogenic source in some localities (Fig. 1). Similar results (pyrogenic sources) were obtained in multiindustrial city in South Korea [26] and urban soil from three European cities: Glasgow (UK), Torino (Italy) and Ljubljana (Slovenia) [7].

Fluo/(Fluo + Pyr) ratios ranged from 0 to 1.35 (mean value of 0.10 ) (Fig. 1). These values indicate that the most likely sources of PAHs is petroleum/ petrogenic source (value $<0.20$ ) [27], except in one location. The above is partially confirmed $\mathrm{BaA} /(\mathrm{BaA}+$ Chr) with values are from 0.021 to 1.42 (mean value of 0.21 ). These values indicate ratio coal combustion and partially petrogenic source and traffic emission in some localities (Fig. 1) [27].

Ratios of IcdP/(IcdP+BghiP) with mean value 0.56 (from 0.2 to 0.78 ) indicated that it is a source of pollution of PAHs coal and biomass combustion and partially fuel combustion (pyrogenic source) (Fig. 1) [28].

Soil samples were heavily impacted by a variety of mixed PAHs sources, where the pyrogenic source is predominant. Petrogenic sources have a significant contribution to the PAHs in the study area.

PCA was adopted to further analyze the influential factors that affected the variation of PAHs components concentration. Percentage of variance explained by each of the first principal components, and total variance explained by the principal components. Distribution of sample scores in PCA can indicate the influencing factors for the comprehensive variation of variables [29]. Each new principal component explains a certain part of the total variance of the system.

Usually, the first principal component (PC1) explains the maximal part of the system variation and each additional $\mathrm{PC}$ has a lesser contribution to the variance explanation [30].

The primary output for a PCA shows the correlation between each variable of a principal component and the variable factors (PC1 and PC2), i.e. elements in soil samples are affected by two major components. Two principal components (PC) with eigenvalues higher than 1 (PC1 and PC2) (Table 2).

The research was applied factor analysis (FA), a type of multivariate statistics, which is used to determine the effective variable factors (compounds). FA was chosen to explain the correlation structure of the 16 PAHs compounds using a smaller number of factors [31]. FA successfully correlated the PAHs components distribution to their main hypothetical origins [32] with the use of varimax rotation (orthogonal rotation that minimises the number of variables). The aim of FA was to create a fewer number of factors by combining two or more variables.

The PC1 factor, which included Ace, Ant, BaA, BaP, BbF, BghiP, BkF, Chr, DahA, Flo, Fluo, IcdP and Phe was identified according to their coefficients in 
Table 2. Component loading for PAHs components, according to factor analysis.

\begin{tabular}{|c|c|c|c|}
\hline & PC 1 & PC 2 & Uniqueness \\
\hline Ace & 0.636 & 0.512 & 0.333 \\
\hline Acy & . & 0.907 & 0.164 \\
\hline Ant & 0.829 & 0.518 & 0.044 \\
\hline $\mathrm{BaA}$ & 0.873 & . & 0.133 \\
\hline $\mathrm{BaP}$ & 0.930 & . & 0.096 \\
\hline $\mathrm{BbF}$ & 0.932 & . & 0.052 \\
\hline BghiP & 0.878 & . & 0.128 \\
\hline $\mathrm{BkF}$ & 0.876 & . & 0.118 \\
\hline Chr & 0.911 & . & 0.080 \\
\hline DahA & 0.858 & . & 0.137 \\
\hline Flo & 0.755 & 0.538 & 0.140 \\
\hline Fluo & 0.871 & 0.428 & 0.057 \\
\hline IcdP & 0.898 & . & 0.088 \\
\hline Nap & . & 0.821 & 0.182 \\
\hline Phe & 0.845 & . & 0.204 \\
\hline Pyr & . & 0.594 & 0.518 \\
\hline Eigenvalue & 12.276 & 1.24957 & \\
\hline Variance (\%) & 76.723 & 7.8098 & \\
\hline $\begin{array}{l}\text { Total variance } \\
\text { (Cum \%) }\end{array}$ & 76.723 & 84.533 & \\
\hline
\end{tabular}

component matrix. The PC1 factor is in relation with burning and was indicative of the coal combustion (pyrogenic origin). Ant, $\mathrm{BaA}, \mathrm{BaP}, \mathrm{BbF}, \mathrm{BghiP}, \mathrm{BkF}$, Chr, DahA, Fluo, IcdP and Phe were strong positively loaded (>0.70) [33], i.e. (>0.75) [34] (Table 2). Among the relevant compounds, Phe, Fluo, $\mathrm{BaA}$, and $\mathrm{Chr}$ are typical markers for coal burning [20]. BbF, BkF, BaP, IcdP, and BghiP are also important markers from the emission of coal combustion [11]. This factor explained $76.72 \%$ of total variance. These results could be linked to the presence of a burning, i.e. coal combustion, suggest that exposure to PAH may be posing an increased risk to human health in locality. The impact of pyrolytic contamination from vehicles is also suggested by the loaded of $\mathrm{Chr}$ and $\mathrm{BaA}$, which are considered components of such combustion processes [35]. Vehicular emissions and residential wood combustion which can all constitute a source of PAHs compounds and contribute to their concentrations in soils and other media [3].

The PC2 factor is petrogenic origin, the PAHs are derived from petroleum spills, probably illegal waste disposal in location (primarily Acy, Nap and Pyr) and explained $7.81 \%$ of total variance. Only statistically significant loadings $(>0.70)$ are important for the modeling and interpretation procedure [30]. Acy and Nap were strong positively loaded $(>0.70)$ [33], i.e. $(>0.75$ ) [34] (Table 2) and characterized by the predominance of 2- or 3-ring PAHs. NAP acts as a marker for oil and petroleum source [36].

Fig. 2a) shows what PCA is done to combine measured variables into a two components, PC1 and $\mathrm{PC} 2$. From the direction of the arrows that the variables (Ace, Acy, Ant, BaA, BaP, BbF, BghiP, BkF, Chr, DahA, Flo, Fluo, IcdP Nap, Phe and Pyr) contribute to the variable factors.

The weights to emphasize Ace, Ant, BaA, BaP, BbF, BghiP, BkF, Chr, DahA, Flo, Fluo, IcdP and Phe (for PC1) and Acy, Nap and Pyr (for PC2) variables more than others.

Using PCA we obtained three factors that clarify the grouping of pollutants: factor $\mathrm{PC} 1$ represents the pyrogenic origin (Ace, Ant, BaA, BaP, BbF, BghiP, a)

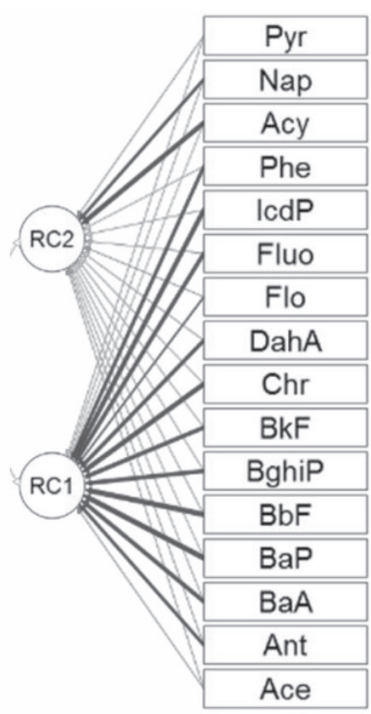

b)

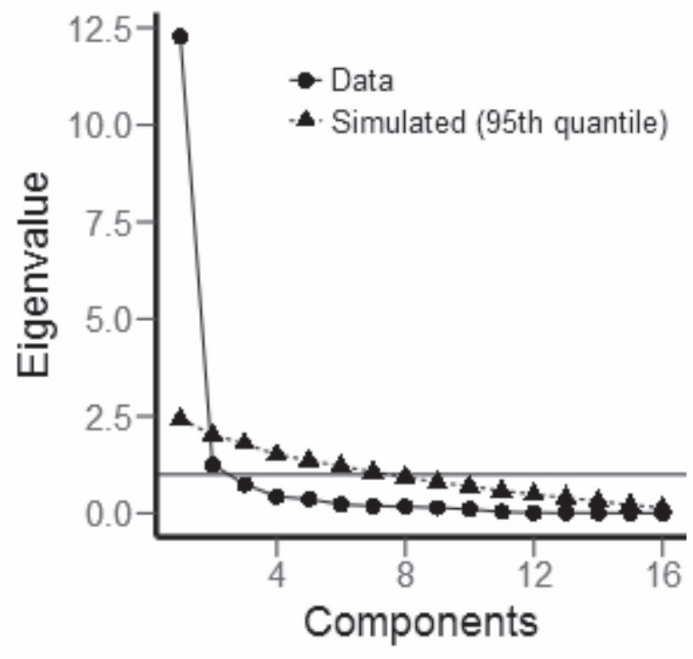

Fig. 2. Path diagram a) and Scree plot b). 


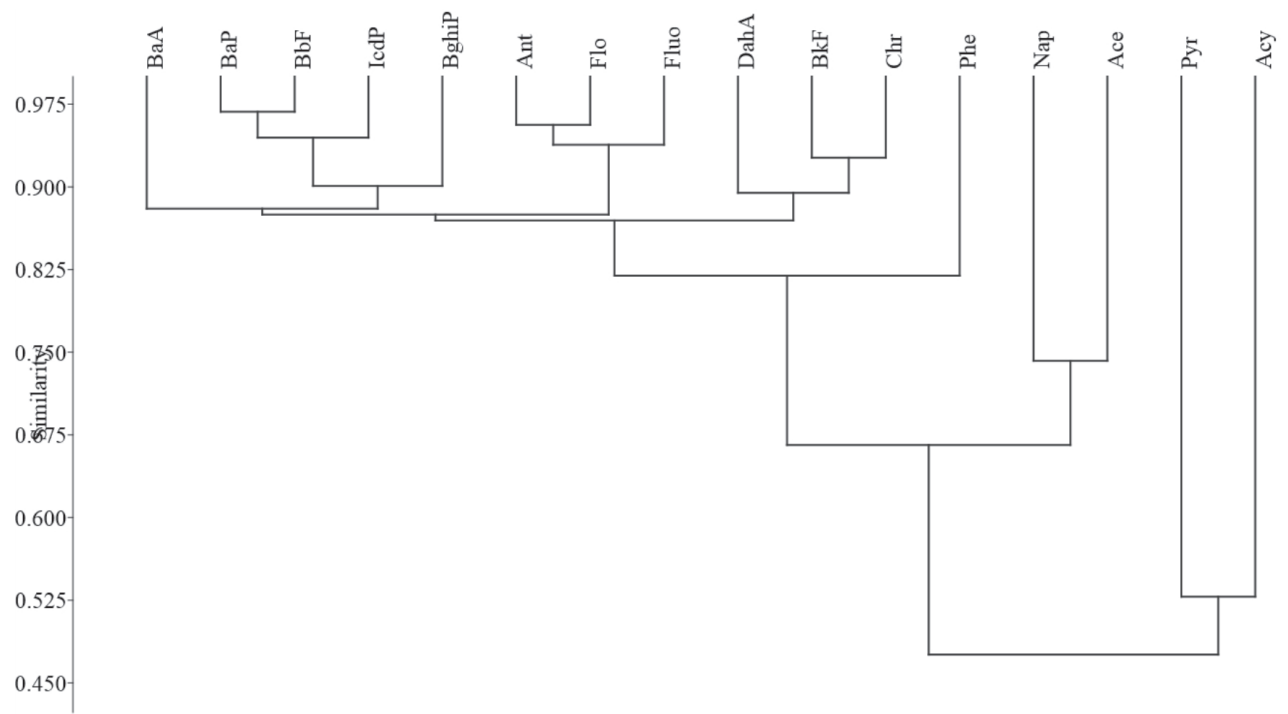

Fig. 3. Results of cluster analysis for PAHs components.

BkF, Chr, DahA, Flo, Fluo, IcdP and Phe) and factor PC2 represents the petrogenic origin (Acy, Nap and Pyr).

Fig. 2b) show PCA scree plot. Eigen values higher than one were taken as a criterion for evaluating the principal components required to explain the sources of variance in the data. According to varimax rotation variance, two factors explained $84.53 \%$ of the data total variance.

In this research, the hierarchical cluster analysis (CA) has been applied to the data, and the Paired group (UPGMA) methods distance have been chosen for calculation. CA was performed to check the results of the PC analysis.

The results of the CA yield a slightly similar result like PCA. From the results, two main groups can be identified. Pyr and Acy and Ace and Nap (Group 1) and other PAHs components (Group 2), which indicated that the pollutants in the similar group might have similar sources (Fig. 3), which was also confirmed by PCA.

In this industrial complex, the construction of commercial and residential buildings is planned. It is imperative to initiate urgent remediation in the location. Several different remediation technologies can be used to remove PAHs in soil [4]. They can be used available remedial options (the most efficient and cost effective) for remove PAHs from contaminated soils, such phytoremediation, thermal conduction, chemical oxidation, incineration, soil washing, composting, bioreactors etc. Integrating biological and physicochemical technologies is also widely practiced for better cleanup of PAHs contaminated soils [36].

In order to choose the best remediation technology, it is necessary to conduct additional research in location, such as vertical and horizontal direction and the extent of the PAHs contaminated soil and potentially groundwater in the industrial complex that are contaminated with PAHs.

\section{Conclusions}

The aim of the study was to measure the PAHs concentrations in soil and to evaluate the sources of the contamination of soils. This study investigated the current status of soil contamination in research area. Total concentrations of the PAHs ranged from 0.36 to $11.49 \mathrm{mg} / \mathrm{kg}$, with mean values of $1.99 \mathrm{mg} / \mathrm{kg}$. Mean values indicated that soil were heavily contaminated $(1 \mathrm{mg} / \mathrm{kg})$ and polluted with III pollution class pollutants ranged from 1 to $5 \mathrm{mg} / \mathrm{kg}$.

Two sources of PAHs were identified by FA analysis: pyrogenic (coal combustion, vehicle emission and incomplete combustion) and petrogenic (from petroleum spills, probably illegal waste disposal in location) sources, which contributed $76.72 \%$ and $7.81 \%$ of total variance, respectively. Diagnostic ratios also showed prevalence of both pyrogenic and petrogenic sources.

The results of this research would be helpful to better understand the sources and toxicities of PAHs in industrial area in Banja Luka and provide significant information in PAHs pollution control.

\section{Acknowledgements}

The present study was conducted using equipment from the PSRI Institute for Protection and Ecology of the Republic of Srpska, Banja Luka. This research was done in the frame of the project "Environmental assessment correlated with the environmental risks in the urban area", granted by the Ministry for Scientific and Technological Development, Higher Education and Information Society of Republic of Srpska (19/6020/961-96/18). 


\section{Conflict of Interest}

The authors declare no conflict of interest.

\section{References}

1. ILIĆ P., NIŠIĆ, T., ILIĆ, S., STOJANOVIĆ BJELIĆ, LJ. The identification of new 'hotspot' of heavy metal contamination of soil in industrial zone. Pol. J. Environ. Stud. 29 (4), 2987, 2020.

2. GUO J., CHAI C., GE W., ZENG L., WU J., XIANG D., ZHANG X. Accumulation and Health Risk Assessment of PAHs in Radish. Pol. J. Environ. Stud. 27 (6), 2529, 2018.

3. THIOMBANE M., ALBANESE S., DI BONITO M., LIMA A., ZUZOLO D., ROLANDI R., QI S., DE VIVO B. Source patterns and contamination level of polycyclic aromatic hydrocarbons (PAHs) in urban and rural areas of Southern Italian soils. Environmental geochemistry and health. 41 (2), 507-, 2019.

4. ABDEL-SHAFY H. I., MANSOUR M. S. M. A review on polycyclic aromatic hydrocarbons: source, environmental impact, effect on human health and remediation. Egypt J Petroleum. 25 (1), 107, 2016.

5. CHENG, Q., GE, W., CHAI, C., WU, J., MA, D., ZENG, L., ZHU X., CHEN Q., LI, J. Polycyclic Aromatic Hydrocarbons in Soil Around Coal-Fired Power Plants in Shandong, China. Pol. J. Environ. Stud. 28 (1), 53, 2019.

6. ZAND A.D., GRATHWOHL P. Enhanced Immobilization of Polycyclic Aromatic Hydrocarbons in Contaminated Soil Using Forest Wood-Derived Biochar and Activated Carbon under Saturated Conditions, and the Importance of Biochar Particle Size. Pol. J. Environ. Stud. 25 (1), 427, 2016.

7. MORILLO E., ROMERO A. S., MAQUEDA C., MADRID L., AJMONE-MARSAN F., GRCMAN H., DAVIDSON C. M., HURSTHOUSE A. S., VILlaVERDE J. Soil pollution by PAHs in urban soils: a comparison of three European cities. Journal of Environmental Monitoring. 9 (9), 1001, 2007.

8. ALSBOU E., ZAITOUN M. A., ALASOUFI A. M., AL SHRA'AH, A. Concentration and Source Assessment of Polycyclic Aromatic Hydrocarbons in the Street Soil of Ma'an City, Jordan. Archives of environmental contamination and toxicology. 77 (4), 619, 2019.

9. BALCIOĞLU E. B., ÇEVIK F. E., AKSU A. Source Determination and Seasonal Distribution of Polycyclic Aromatic Hydrocarbons (PAHs) in Urban Soil of the Megacity Istanbul. Polycyclic Aromatic Compounds. 1-9, 2019.

10. CIARKOWSKA K., GAMBUS F., ANTONKIEWICZ J., KOLIOPOULOS T. Polycyclic aromatic hydrocarbon and heavy metal contents in the urban soils in southern Poland. Chemosphere. 229, 214, 2019.

11. WANG C., WU S., ZHOU S., WANG H., LI B., CHEN H., YU Y., SHI Y. Polycyclic aromatic hydrocarbons in soils from urban to rural areas in Nanjing: concentration, source, spatial distribution, and potential human health risk. Sci. Total Environ. 375, 527, 2015.

12. KAMAL A., MALIK R.N., MARTELLINI T., CINCINELLI A. Cancer risk evaluation of brick kiln workers exposed to dust bound PAHs in Punjab province (Pakistan). Sci Total Environ. 493, 562, 2014.

13. DING Y., HUANG H., ZHANG Y., ZHENG H., ZENG F., CHEN W., QU C., LI X., QI S. Polycyclic aromatic hydrocarbons in agricultural soils from Northwest Fujian, Southeast China: Spatial distribution, source apportionment, and toxicity evaluation. Journal of Geochemical Exploration. 195, 121, 2018.

14. TANG L., TANG X.Y., ZHU Y.G., ZHENG M.H., MIAO Q.L. Contamination of polycyclic aromatic hydrocarbons (PAHs) in urban soils in Beijing, China. Environ Int. 31 (6), 822, 2005.

15. HU N., HUANG P., LIU J., MA D., SHI X., MAO J., LIU Y. Characterization and source apportionment of polycyclic aromatic hydrocarbons (PAHs) in sediments in the Yellow River Estuary, China. Environ Earth Sci. 71 (2), 873, 2014.

16. RULEBOOK on allowable quantities of dangerous and hazardous matters in soil and irrigation water and methods for their testing ("Official Gazette of the Republic of Srpska”, No. 56/16), 2016 [In Serbian].

17. KONSTANTINOVA E., MINKINA T., SUSHKOVA S., ANTONENKO E., KONSTANTINOV A. Levels, sources, and toxicity assessment of polycyclic aromatic hydrocarbons in urban topsoils of an intensively developing Western Siberian city. Environmental Geochemistry and Health. 1-17, 2019.

18. MALAWSKA M., WIOŁKOMIRSKI B. An analysis of soil and plant (Taraxacum officinale) contamination with heavy metals and polycyclic aromatic hydrocarbons (PAHs) in the area of the railway junction Iława Główna, Poland. Water, Air, and Soil Pollution. 127 (1-4), 339, 2001.

19. CACHADA A., DIAS A. C., REIS A. P., FERREIRA DA SILVA E., PEREIRA R., DUARTE A. D. C., PATINHA C. Multivariate Analysis for Assessing Sources, and Potential Risks of Polycyclic Aromatic Hydrocarbons in Lisbon Urban Soils. Minerals. 9 (3), 139, 2019.

20. HARRISON R.M., SMITH D.J.T., LUHANA L. Source apportionment of atmospheric polycyclic aromatic hydrocarbons collected from an urban location in Birmingham, UK. Environ. Sci. Technol. 30 (3), 825, 1996.

21. LINHUA S., SONGBAO F. Heavy Metals in the Surface Soil around a Coalmine: Pollution Assessment and Source Identification. Pol. J. Environ. Stud. 28 (4), 2717, 2019.

22. CEPA (Chinese Environmental Protection Administration). Elemental background values of soils in China. Environmental Science Press of China, Beijing, 1990.

23. SUN L., PENG W., CHENG C. Source estimating of heavy metals in shallow groundwater based on UNMIX Model: a case study. Indian Journal of Geo-Marine Sciences. 45 (6), 756, 2016.

24. GAO P., XU M., LIU Y., DA SILVA E. B., XIANG P., MA L. Q. Emerging and legacy PAHs in urban soils of four small cities: Concentrations, distribution, and sources. Science of the Total Environment. 685, 463, 2019.

25. BUDZINSKI H., JONES I., BELLOCQ J., PIERARD C., GARRIGUES P. Evaluation of sediment contamination by polycyclic aromatic hydrocarbons in the Gironde estuary. Marine Chemistry. 58, 85, 1997.

26. KWON H.O., CHOI S.D. Polycyclic aromatic hydrocarbons (PAHs) in soils from a multi-industrial city, South Korea. Sci Total Environ. 470-471, 1494, 2014.

27. YUNKER M.B., MACDONALD R.W., VINGARZAN R., MITCHELL R.H., GOYETTE D., SYLVESTRE S. PAHs in the Fraser river basin: A critical appraisal of PAH ratios as indicators of PAH source and composition. Organic Geochemistry. 33, 489, 2002.

28. TOBISZEWSKI M., NAMIEŚNIK J. PAH diagnostic ratios for the identification of pollution emission sources. Environmental Pollution. 162, 110, 2012. 
29. RIVETTI C., LÓPEZ-PEREA J. J., LAGUNA C., PIÑA B., MATEO R., ELJARRAT, E., BARCELÓ, D., BARATA, C. Integrated environmental risk assessment of chemical pollution in a Mediterranean floodplain by combining chemical and biological methods. Sci. Total Environ. 583, 248, 2017.

30. NEDYALKOVA M., SIMEONOV V. Chemomertic Risk Assessment of Soil Pollution. Open Chemistry. 17 (1), 711, 2019.

31. REIMANN C., FILZMOSER P., GARRETT R. Factor analysis applied to regional geochemical data: Problems and possibilities. Applied Geochemistry, 17 (3), 185, 2002.

32. ISLAM M.N., PARK M., JO Y.T., NGUYEN X.P., PARK S.S., CHUNG S.Y., PARK J.H. Distribution, sources, and toxicity assessment of polycyclic aromatic hydrocarbons in surface soils of the Gwangju City, Korea. Journal of Geochemical Exploration. 180, 52, 2017.

33. TEPANOSYAN G., SAHAKYAN L., BELYAEVA O., MAGHAKYAN N., SAGHATELYAN A. Human health risk assessment and riskiest heavy metal origin identification in urban soils of Yerevan, Armenia. Chemosphere. 184, 1230, 2017.
34. LIU C.W., LIN K.H., KUO Y.M. Application of factor analysis in the assessment of groundwater quality in a Blackfoot disease area in Taiwan. Science of the Total Environment. 313 (1-3), 77, 2003.

35. AZIMI S., ROCHER V., MULLER M., MOILLERON R. THEVENOT D. R. Sources, distribution and variability of hydrocarbons and metals in atmospheric deposition in an urban area (Paris, France), Sci. Total Environ. 337, 223, 2005.

36. BAO H., HOU S., NIU H., TIAN K., LIU X., WU F. Status, sources, and risk assessment of polycyclic aromatic hydrocarbons in urban soils of Xi'an, China. Environmental Science and Pollution Research. 25 (19), 18947, 2018.

37. KUPPUSAMY S., THAVAMANI P., VENKATESWARLU K., LEE Y.B., NAIDU R., MEGHARAJ M. Remediation approaches for polycyclic aromatic hydrocarbons (PAHs) contaminated soils: Technological constraints, emerging trends and future directions. Chemosphere. 168, 944, 2017. 